石油技泪势会誌 第 22 卷 第 1 号（昭和 32 年 1 月）

JOURNAL OF THE JAPANESE ASSOCIATION OF PETROLEUM TECHNOLOGISTS

VOL. 22, NO. 1 (Janu, 1957)

岩石掘鏊用ハードメタル試験の実際

中 山好弘*

(明和 31 年 11 月 24 日受理)

Study on Drillability of Bit

By

\title{
Yoshihiro NAKAYAMA
}

\begin{abstract}
This report is a part of study on the relationship between hard metal particle effect or self cutting effect and wear. And many sorts of deformation of the drill-bit-tooth which occur during long drilling as a result of ex:essive load are mainly discussed in the report.
\end{abstract}

\section{緒 言}

掘錅中のビツトの刃先状態を仔細に検傠すると，種ぬ の複雑な運動機構の集合から成り立つているととがわか る。しかして, これらビットは従来から，使用目的なら びに使用条件等に従がつて適切な型式が採用されている 炕もかつわらず，刃先の硬装（ハードフェーシング）掠

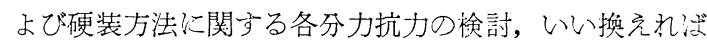
刃先の主要運動機構に対する適合性について, 幾名の課 題を残しているのが現状である。石油掘鳘用ビットの基 脴掘進理論については, 目下精密に追究されつつあるの で, ことでは掘進要素の一部をなす超硬質合金硬装材 （ハードメタル）炈いての筆者等担当の試験の過程に あつて，その一端を紹介するものである。

\section{刃先におけるハードメタルの役割}

岩石掘進にさいして，いかなるビットも鋼のまきで依 良好なる成果望望え妨とと、，今日では最早一般化さ れたととであり，刃先の肝心な部分を超硬質合金で保護 するととは，例外なく奏施されているのである。たとえ ばフイシニティルビットのどとき簡単な刃にあつては, 往時, 盛んKステライト・ヘイステライト等の硬質合全 が使用された。とれは刃先の磨隇学防ぐ意図にもとづ き, ビットの刃先原形を長く持続せしめ, むつて掘進の 結局効果を得るにあつたことが主要な点である。この際 刃先の店滅によつて徐々に掘籢力が低下することは, 磨

\footnotetext{
* 带国石油秘式会社 技術研究所
}

減によつて刃先断面が拡大し, 刃面単位荷重が低下する 心厓䒕らない。通常, いわ的軟質岩にあつては, 磨 耗の変化に対尗る掘籢力の変化は緩曲線状に示され，や 〉硬質岩にあつては，著しく掘進率を低下する部分を有

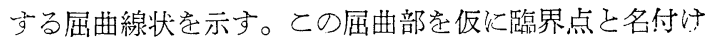
るなら出，この郜界点以下の掘進機構条件下に牥いて は, 刃面下に受ける単位荷重㤁，その岩石の弾性強度孛 越えざる状態と考えられ，乙の掘進状態に打いて掘屑量 訬なく, かつ, 掘屑中微粉末の吕める割合が多い。ま た, 臨界点以上では弾性強度を越えて, いわゆる择掘機 構が加わつているとと定示し, 掘屑分析に执いては, 明 らかに掻堀作用字示す特有な扁平状掘屑を多量混入す る。しかし，いずれにしても刃面が坑底を圧擦している 以上, 表面の結晶質ないし分子の歪による破壊 (ここで は掘進の一部乞見る）が，ともに存在していると亡は認 めねばならない(第 1 図参照)。すなわち当初の刃面が, この単位荷重上の関係で最初の掘進機構が決り, 掻掘作 用の時間的な長さ柱, 穈耗早さに起因する上記臨界点到 達の早さによつて決末るのであるが，刃先湶しき磨耗 を与えるごとき結晶粒からなる岩石岩にあつては，特に 掻掘範囲が狭りごく硬質岩にあつては, 弾性強度特に大 なるため，単位荷重は容易にこれを越え得ず，試栓 荷重を增大しても，当初掘籢力向上顥著なものがある

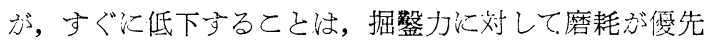
する不合理な状態を示すものである。

しかし, 近来, 粒子状ハードメタルの良質のものが使 
好弘

第 1 図掘進状態の 2 態様
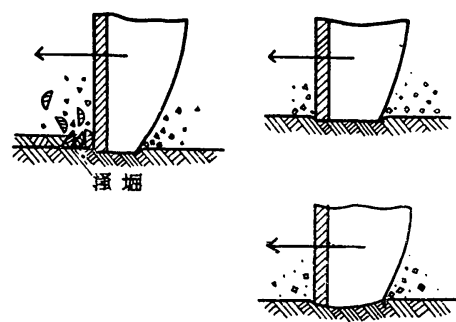

（上図は典型図，右下は実際図）

用されるに至つて, 刃面積が拡大しても, な掞良好な掘 進を持続することがある程度可能となつた。すなわち， これによれば，ハードメタル粒、子を刃面に適当に散布熔 着し, 硬装体自身に受ける単位荷重と, 刃面母材部に加 わる糜耗抗抵との釣合いによつて, 有効な掘進を持続し 得るのである。末た同様な理由の下に, 超硬質合全チッ プを刃先に並列的に配置熔着するととも行われている。 しかし，これとても刃先の鋭利な方が掘鳘力は良好なの であるから，刃断面に基づく掘警力と，硬装执よび硬装 方法による掘錅力との 2 元的の要素から成立つているこ とが了解される。ブレードビットは普通, 常識上して掻 掘作用のみについて云々される。しかし, 筆者等の行つ た試験は，特に短孔掘進による比較試験であるから，い き执使用岩石は比較的硬質岩が多く, それらの示す掘 進率程度では刃の進行ピツ チが微少で，乙れが圧入原 理以前の場合が多く, 弾性 強度について問題とするの もこれがためである。

\section{ソリツドェツヂ 比較試験}

硬装刃面は通常硬装面と 母材面から成立つが，掘鎑 力讨両者の耐磨耗性 $\left(\mathrm{H}^{*}\right)$ の相関関係に起因し，かつ 刃先の磨耗を示すとと前述 の通りである。しかしなが らハードメタルの本質的な 掘進・磨耗の相対值は, 前 記母材部のごとき複次要素 を排除しなければ正確を期 し難い。したがつて本項実 験においては, ハードメタ ルチップのみ突出せしめ，

第 2 図使用ビッド
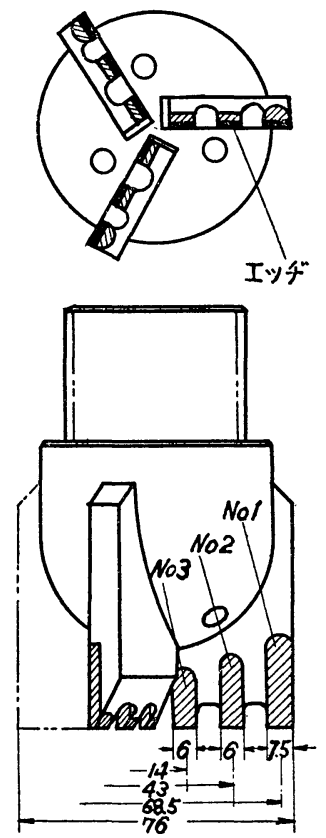

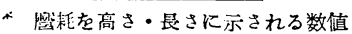

いわゆるソリッドェッチの形で, ハードメタルの磨耗速 度 $\left(\mathrm{V}^{* *}\right)$ と掘籢力との比較試験を行つたのである。だ゙ しこの際の磨耗速度とは, 掘進率に基づく当岩石坑底の の磨擦条件 $\mu$ の変化との相対磨耗値であることを附言 する。なお磨耗量 (V) は断面積変化に基づき計算して 得たものである。

比較試料

イ 焼結法により製造した $10 \%$ Co ドリロイチップ (帝石製)

ロ＼cjkstart熔融法により鋳造されたコバルトボリアム（米国 製)

第 1 表

\begin{tabular}{|c|c|c|c|c|c|c|c|}
\hline \multirow{2}{*}{ チップ名 } & \multirow{2}{*}{$\begin{array}{l}1 \text { 丁に付 } \\
\text { 植 込 数 }\end{array}$} & \multirow{2}{*}{ 製法 } & \multirow{2}{*}{ 硬度 } & \multicolumn{4}{|c|}{ 分 析 值 } \\
\hline & & & & W & $\mathrm{C}$ & Co & $\mathrm{Fe}$ \\
\hline $\begin{array}{l}\text { ドリロイ } \\
\text { チップ }\end{array}$ & $\begin{array}{r}7.5 \mathrm{~mm} \text { 幅 } 3 \\
6 \mathrm{~mm} \text { 幅 } 6\end{array}$ & 焼結 & RA 88 & 86.0 & 4.0 & 10.0 & \\
\hline $\begin{array}{l}\text { コバルト } \\
\text { ボリアム }\end{array}$ & " & 鋳造 & RA 80 & 79.0 & 4.0 & 12.0 & 4.0 \\
\hline
\end{tabular}

使用ビット…3 时 3 枚刃，各チップ等間隔配列（第 2 図参照)

使用条件……岩石：硬質花崗岩（硬度未測）

荷重： $1,000 \mathrm{~kg}$

湎転：90 r.p.m.

第 4 表に示すグラフは第 2 表，第 3 表の試験結果より 算出したものである。横軸には単位荷重の大さを取り, 縦軸にこれに対する 1 分当り磨耗量を示した。第 4 表は

第 2 表 断面積々掘進率々の関係 (ボリアムチップ)

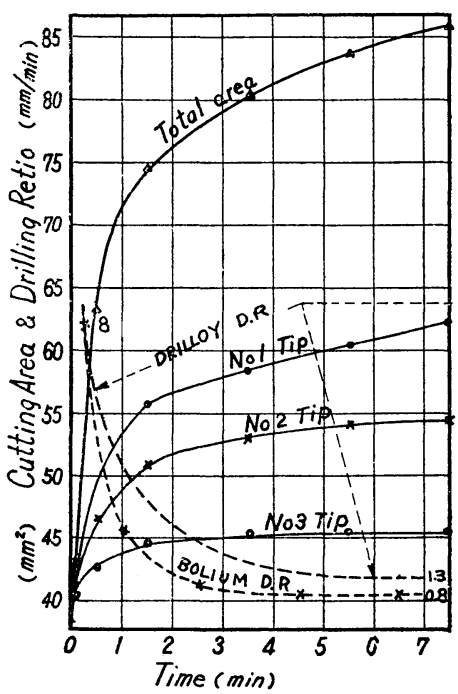

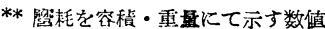


第 3 表 ドリロイチップ

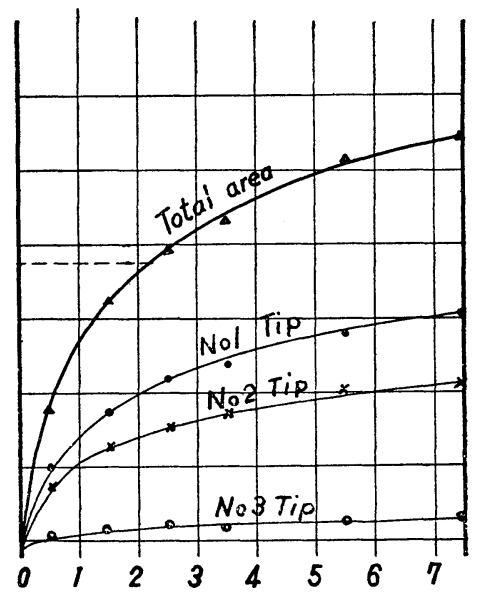

(花崗岩 $W_{T}=1,000 \mathrm{~kg}, \mathrm{~N}=90 \mathrm{RPM}$ )

第 4 表 単位荷重に対するエツヂ磨粆速度 (ボリアムとドリロイ)

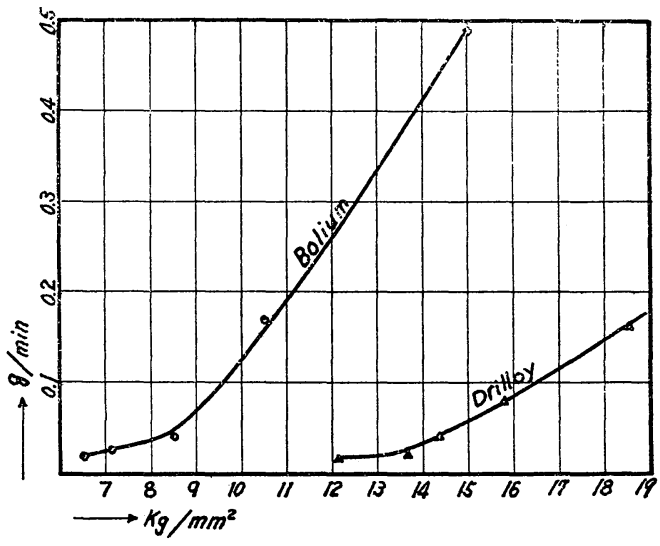

(花崗岩 $W_{T}=1,000 \mathrm{~kg}, \mathrm{~N}=90 \mathrm{RPM}$ )

両チップが花崗岩掘警に示す特性であるが，こ〉ではここ の曲線に対する詳細な説明は省略する。

\section{粒子硬裝について}

同質のハードメタルに関する限り，磨耗速度 $(\mathrm{H})$ の比 較は坑底に接触する面積飞支配されることは当然であ る。したがつて, 硬装が同厚である時, いわゆる「心゙夕」 硬装(硬質合金平板を溶着しふでとき刃, ステライト硬装 も同式）之粒子硬装の比較は，刃の磨耗の及についての み云タするならば前者の優れているととは朋瞭である。 故に，刃先儿対し，激しき磨耗作用を与えないような歅 質岩掘籢に際しては，粒子効果を期街するよりまず緻 密な硬装によつて, 刃先の磨耗変形を防ぐ意味の方がよ り重要である。このような時, 具際には小粒子をもつて 密度大に硬装するか，あるいは，乙れによつて反つて硬
第 5 表 各種熔着材による掘進の変化

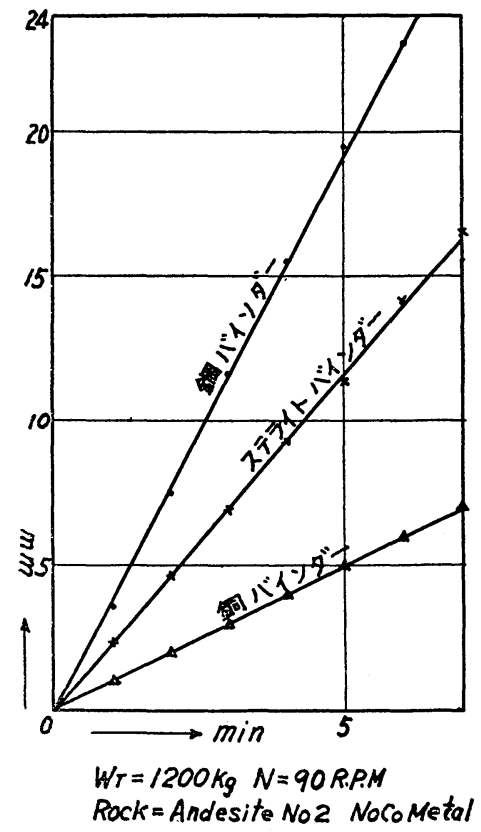

装母体を衝撃等に対して脆弱化するおそれのある時忍， 大粒子とその空間を 適度に占める 小粒子とが 混合され る。しかし比較的硬質岩にあつて, 有効的な粒子効果を ねららならば, 比較的大粒子のものを選択し, かつ熔着 材はハードメタルの耐磨性にかなう適度の硬さのものが 望末しいのてある(第5 表参照)。

\section{粒子効果について}

粒子硬装が特有の掘籢效果を示すとと, 前述の通りで あるが，その原理扢々び系統的な研究については詳らか でない。たぶ, 刃先面に抢ける硬装部と, 熔着材ないし 支持材との相互に介在する形式化めつては，第 3 図イに 示すチップの配列形と類似の点学認めるととができるか ら，との場合も硬洼粒子と粒子間の熔着材，支持材の而 磨性の相互関係に起因するのである。との際, 刃面の忘 力分布の方る部分部分が仮に岩石の弾性強度导越えてい る場合, 部分的择掘現㧻を起しているか否か心, 掘屑分 析の集計を待心放谋結論となし得ない。との绿かに考え られる粒子効果としては, 刃面の凹凹の生成により,岩面 上の接触作用面の增大汇よるとこが考えられる。この作 用は掘屑中微粉混入率の多星により推定し得る。第 5 図 は硬装部と支持母材の磨耗速度との相互関係が掘警力学 示した実際の例である。この際，硬装部を粒子と置換え た典型図字第 3 図に示す。との磨耗速度㤁，通常の容積 磨耗係数をHに换算した磨耗速度係数である。しかして

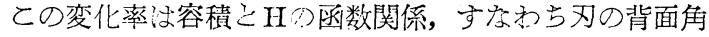


第 3 図

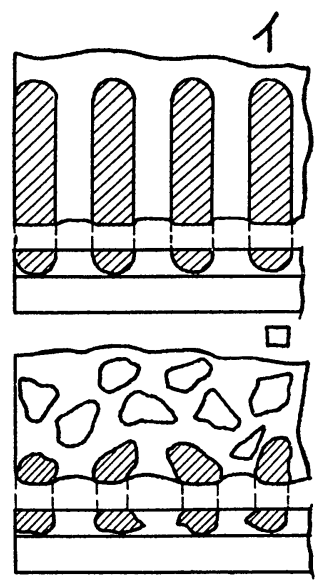

第 4 図 忘力分有図

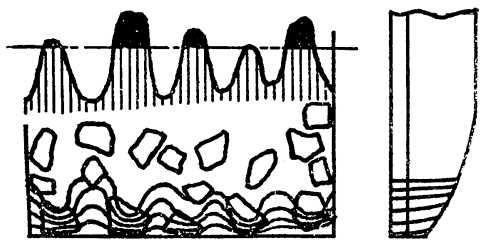

第 5 図チップと母材の磨粍比々 掘進状態との比較
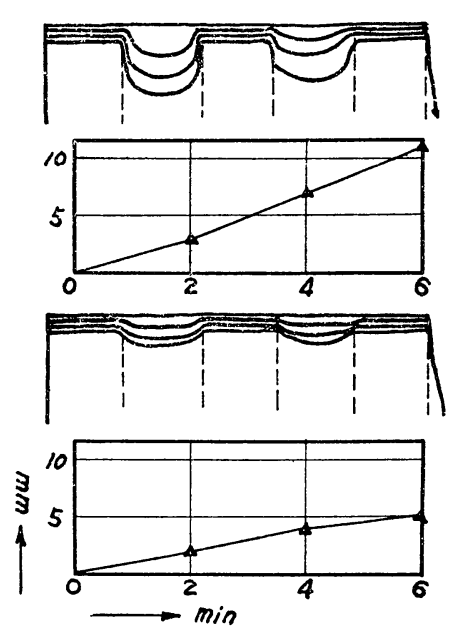

(測定 2 分每, 上 $\mathrm{B} \times$ タル,下W×タル)

抬よで硬装面変化炕基づき決定される。ゆネれ，磨耗速

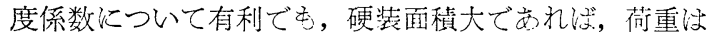
分散し, 掘進に効し有効的でない（ミざし，刐先の磨滅 に対しては有效的である）。梞た，逆汇硪装面積が小で あれば，磨耗速度係数は目材のそれと近接するので, 掘 進・榃耗ともに有効的でないここ㭁わかる。すなわち，
第 6 表 ベタ硬装と粒子硬装掘進形態の比較例

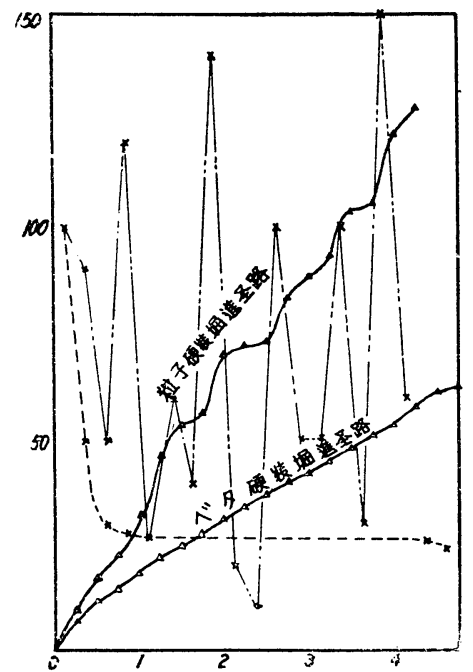

ベタ硬装：ドリロイプレート $2 \mathrm{~m}$ 張付

粒子硬装：ボリアムチューブメタル 10～20 メッシニ

あるハードメタル淰，ある刃面についてその掘鳘力が最 む有効的に示される硬装適晹があるわけである。硬装適 量に対する磨耗值を母材材質との相対飞执て求めたも のが粒子效果として示されるが,この値は,ハードメタル の性質により粒子効果の暴なるととが予想されるので， 結論态では相当長期の試験を続行する要す。后本試 験に必要な僢間掘進率計は，目下試作の途次にある。

\section{比較試験用ブレードについて}

本頃についてい上述の基礎試験とは別に，早急的な八 ードメタル比較試験亡して，大略の目的に沿うょう，別 に奉施されたものである。試験の性格としては，比較試 験の趣旨に基づき, 幾分定性試験の傾向孛ま妨れない。 衆知のごレく，ブレードビット住本来比較的軟岩に詨 し利用され，この性能は刃面効果および粒子(チップを含 む) 効果の徐々になる変化の結局効果, すなわち長坑掘 進の結果, 総寔的に示されるものであるから，圧縮され た短孔掘進で比䡬するととには，種々の問題点がある。 浢孔硬質掘籢に执いて注，前述のでとく，择掘範囲がき

写真 Yilld Point（掘進率の顕著な降下点） に把ける 2 種メタルの比較

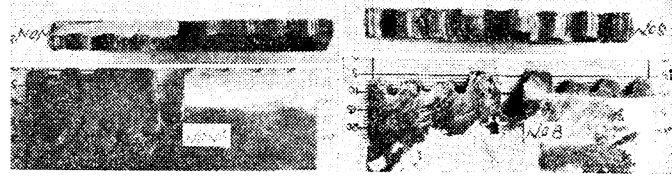

(左図: $\mathrm{B} \times$ タ，右図： $\mathrm{A} \times$ タル) 
わめて狭く, かつその移行点が比較的明確であるので, 掘進の㳭とんどが圧擦により行われる。ところが実際に

「掘る」任事は择掘により強くエツヂに作用させ，ハー ドメタルのエツヂ性能についても加味ず゙きが至当であ ると考え，第 5 図のごとき試験ブレードを試作した。

すなわちとの方式によれば，硬質岩にかかわらず，ブ レードは最初掻掘をすつて始索り，磨耗儿従がつて圧擦 面を増し, 荷重分均一ないわわる平衡点心洼するとき 㤈, 厓々んご压擦が占める微量掘進である。ブレードの 構造柱第 6 図のごとく, 一定断面を有する刃部と磨耗抵

第 6 図比較試験用ブレード把よび比較例

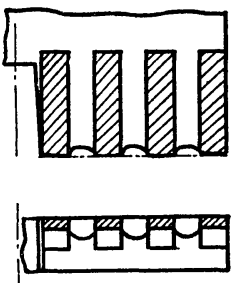

不良メタル

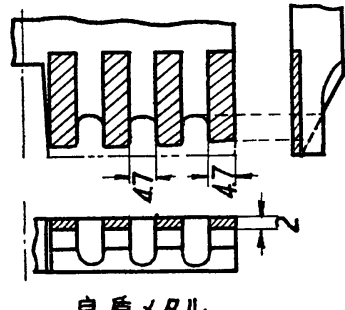

良稹メタル
抗を与え，かつそれが刻くと增大するような母材の組合 过から成りたつている。測定はその間の掘進総量と, 刃 面各部の釣合状態とによつて検討する。尔た，功な 硬装部を独立配置する方法は, この種試験に見られるよ うな, 甚だしい偏り磨耗から救うことができる。偏り磨 耗洁試験ブレードが小経であるに反して, 粒子は实際の 大さであり, 刃面各部の硬装量密度偏差が, 奏物大ビッ トより遙かに大で, このととは掘進測定の構確度を著し
く妨書するので，このととは全試験を通じて特別な注意 を仏わねばならぬ点である。

第 7 図に試験ブレード揖よび普通ブレードの磨耗状態 を示す。

第 7 図
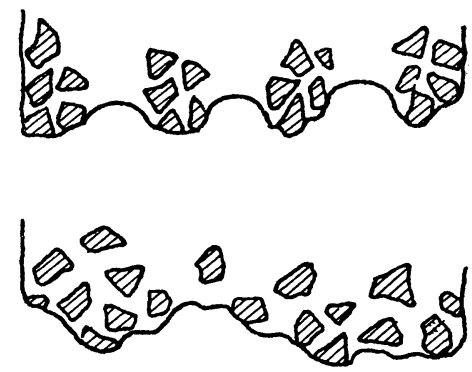

（上図：比較試験用ブレードの磨粍及先）

(下図 : ブレードの偏磨粍多先)

\section{後 記}

ハードメタルの性能，执よび硬装法に基づく掘警力の 研究は，すべてビットや岩石学媒介として行われるもの であるから，決して単独に結論づけられるものではな い。すなわち， メタル本質としての治金的諸問題・掘蟼 理論・岩石の性質, 等広筙な関連㞭もつているのであ る。

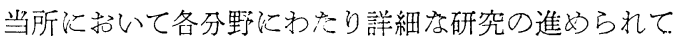
いる際であり, 本文データの解析は検討の余地を残して 一部省略した。以上試験の概略について説明した次第で ある。 